\title{
EFEK MODEL PROBLEM BASED LEARNING (PBL) DAN KONVENSIONAL TERHADAP HASIL BELAJAR SISWA FISIKA
}

\author{
Ahmad Fauzi Pohan ${ }^{1)}$. \\ ${ }^{1}$ Program Studi Teknik Pertambangan, Sekolah Tinggi Teknologi Industri (STTIND) Padang.
}

\begin{abstract}
This aim of this study to determine the effects of problem based learning to learning outcomes. This research sample was taken two classes with simple random sampling that are IX-3 and IX2 to experiment group and control group are 35 students respectively. The average scores result pretest both of treatment group and control group, was 35.29 and 34.86. The average scores result post-test both of the treatment group and control group, was 60.43 and 54.43. The scores pre and post-test mentioned T-test two parties, and the result of the detached score of pre-test obtained $t_{\text {count }}<t_{\text {table }}$, that the initial ability of students both of groups are same, while the T-test results for score post-test obtained $t_{\text {count }}>t_{\text {table }}$, that there is a difference in student learning outcomes with applying problem based learning with conventional learning models.
\end{abstract}

Keywords: Problem Based Learning, Conventional, Simple Random Sampling.

\section{PENDAHULUAN}

Sains merupakan suatu ilmu yang tersusun secara sistematik dan terbatas pada gejala-gejala alam. Perkembangannya tidak hanya ditandai oleh adanya kumpulan fakta, tetapi oleh adanya metode ilmiah dan sikap ilmiah. Pada proses belajar mengajar pengembangan sikap ilmiah ini diperlukan suatu pendekatan yang berpusat pada siswa (student centered) untuk mempelajari konsep dan mencari hal-hal yang baru (Akinoglu dan Ruhan, 2007).

Salah satu masalah yang dihadapi dalam dunia pendidikan kita adalah lemahnya sikap ilmiah dalam proses pembelajaran. Siswa kurang didorong untuk mengembangkan kemampuan berpikir. Akan tetapi siswa hanya diarahkan untuk menghafal informasi tanpa dituntut untuk memahami informasi dan menghubungkannya dengan kehidupan seharihari.

Peneliti menemukan fakta tentang lemahnya sikap ilmiah siswa, setelah melakukan observasi awal sebanyak dua kali di SMP N 5 P. Siantar pada tanggal 30 Januari 2012 dan 11 Februari 2012. Proses belajar mengajar yang penulis amati hanya berpusat pada guru (teacher centered). Selain itu, penulis menemukan rendahnya hasil belajar siswa terutama pada mata pelajaran fisika. Dari hasil wawancara dengan Bapak Efriandi Purba selaku guru mata pelajaran fisika di SMP N 5 P.Siantar mengatakan hasil belajar siswa masih dibawah standart, dimana $60 \%$ siswa yang memiliki nilai > 60, sedangkan $40 \%$ siswa selebihnya memiliki $<60$. Selain itu beliau juga belum pernah menggunakan model problem based learning (PBL) di sekolah tersebut.

Model PBL dapat melatih komponenkomponen berpikir, karena model ini memiliki lima sintaks, yaitu (1). memberikan orientasi tentang permasalahannya kepada peserta didik, (2) mengorganisasikan peserta didik untuk meneliti, (3). membantu investigasi mandiri dan kelompok, (4) mengembangkan dan mempresentasikan artefak dan exibit, dan (5) menganalisis dan mengevaluasi proses mengatasi masalah, selain itu model ini memiliki ciri siswa bekerja sama dalam kelompok kecil sehingga dapat memotivasi siswa secara berkelanjutan terlibat dalam tugas-tugas kompleks dan berpeluang agar siswa melakukan discovery (menemukan) dan berdialog untuk mengembangkan keterampilan berpikir dan meningkatkan hasil belajar (Arends, 2004).

Berdasarkan peneliti sebelumnya yang telah menggunakan model PBL diantaranya, Hayati (2011) menerapkan model pembelajaran berdasarkan masalah untuk materi pokok cahaya. Sibarani (2011) mengetahui pengaruh model tersebut terhadap kemampuan berpikir kritis siswa pada materi usaha dan energi. Rika (2009) mengetahui perbedaan hasil belajar yang diajarkan dengan model tersebut pada materi pokok usaha dan energi. Hasil ketiga peneliti ini menunjukkan 
peningkatan hasil belajar yang dilihat dari nilai-nilai postestnya.

Selain itu penelitian oleh Setiawan (2008) dan Tika (2008) menunjukkan hasil peningkatan aktivitas dan kemampuan berpikir siswa dalam penerapan model PBL baik untuk mata pelajaran biologi maupun fisika.

Berdasarkan masalah yang dihadapi dan keberhasilan penelitian terdahulu penulis berkeinginan untuk mengetahui pengaruh perbedaan hasil dan aktivitas belajar antara menggunakan model PBL dengan model konvensional pada materi pokok listrik dinamis di SMP N 5 P.Siantar. Penelitian ini berbeda dari penelitian-penelitian yang terdahulu baik dari segi lokasi penelitian, materi yang digunakan dan waktu pelaksanaan penelitian. Selain itu peneliti di dalam Rencana Pelaksanaan Pembelajaran menambahkan metode eksperimen sebanyak dua kali. Sehingga penelitian kali ini diharapkan lebih dapat meningkatkan hasil belajar dan aktivitas belajarnya dalam pemecahan masalah yang diberikan kepada siswa.

\section{METODE PENELITIAN}

\subsection{Lokasi dan Waktu Penelitian}

Penelitian ini dilakukan di SMP N 5 Pematangsiantar yang beralamat Jl. Kornel Simanjuntak, Kec. Siantar Kota Pematangsiantar. Objek penelitian ini siswa kelas IX semester I SMP N 5 Pematangsiantar, dan dipilih dua kelas dengan teknik simple random sampling.

\subsection{Variabel Penelitian}

Variabel penelitian terdiri dari:

1. Variabel bebas yaitu penerapan model PBL dan pembelajaran langsung.

2. Variabel terikat yaitu, hasil belajar siswa pada materi listrik dinamis.

\subsection{Jenis dan Desain Penelitian}

Jenis penelitian ini termasuk penelitian quasi eksperimen, yaitu penelitian yang bertujuan mengetahui ada tidaknya perbedaan akibat pengaruh dari "sesuatu" yang dikenakan pada "subjek" yaitu siswa. Pengaruh yang dimaksud adalah hasil belajar siswa dengan model pembelajaran yang telah ditentukan dapat dilihat dari hasil jawaban siswa pada tes hasil belajar (Arikunto, 2002).
Desain penelitian ini melibatkan dua kelas yang diberikan perlakuan yang berbeda, seperti pada Tabel 1 .

Tabel 1. Desain Penelitian

\section{No Kelompok Pretes Perlakuan Postes}

\begin{tabular}{llccc}
\hline 1 & Kelas & $\mathrm{T} 1$ & $\mathrm{X}$ & $\mathrm{T} 2$ \\
& Eksperimen & & $\mathrm{Y}$ & $\mathrm{T} 2$ \\
\hline
\end{tabular}

\section{Keterangan:}

T1 : Pretes diberikan kepada kedua kelas sebelum perlakuan

$\mathrm{X}$ : Pengajaran dengan model PBL

$\mathrm{Y}$ : pengajaran dengan model konvensional

T2: Postes diberikan kepada kedua kelas setelah perlakuan

T1 sama dengan T2

\subsection{Teknik Pengumpulan Data}

Sebelum melakukan kegiatan pembelajaran, dilakukan tes awal (pretes) yang berjumlah 20 soal untuk mengetahui tingkat kemampuan awal siswa dalam materi listrik dinamis pada kedua kelas yang diteliti. Dilanjutkan pemberian materi listrik dinamis dengan kedua model yang sudah ditentukan. Setelah materi diajarkan maka dilaksanakan postes untuk mengetahui hasil belajar siswa pada kelas kontrol maupun eksperimen. Seperti pada Gambar 1.

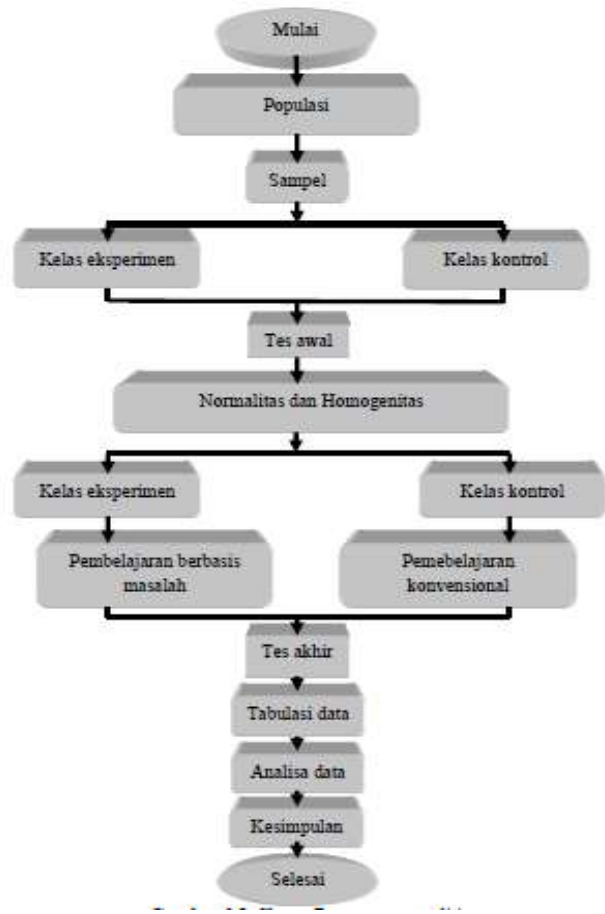

Gambar 1. Diagram Alir Penelitian 
Setelah pengumpulan data kemudian data ditabulasi, dan dianalisis hasil yang diperoleh dengan menghitung rata-rata, uji normalitas ,dan uji homogenitas, kemudian dibandingkan dengan hasil penelitiaan sebelumnya dan ditarik kesimpulan yang diperoleh (Sudjana, 2005).

\section{HASIL DAN PEMBAHASAN}

\subsection{Hasil Belajar Siswa}

Kedua hasil pretes maupun postes terlebih dahulu dilakukan uji normalitas dan homogenitas yang ditunjukkan pada Tabel 2 dan Tabel 3 merupakan ringkasan hasil normalitas dan uji homogenitas kelas eksperimen maupun kelas kontrol. Dari kedua uji tersebut menyatakan bahwa data tersebut normal $\left(\mathrm{L}_{\text {hitung }}<\mathrm{L}_{\text {tabel }}\right)$ dan homogen $\left(\mathrm{F}_{\text {hitung }}<\right.$ $\left.\mathrm{F}_{\text {tabel }}\right)$. Sehingga layak untuk dilanjutkan analisis data berikutnya.

Hasil nilai pretes yang diperoleh pada Gambar 2. menunjukkan nilai tertinggi untuk kelas eksperimen 55,00 dan nilai terendah 15,00. Adapun untuk nilai tertinggi kelas kontrol 55,00 dan 10,00 untuk nilai terendah. Dari hasil tersebut diperoleh nilai rata-rata pretes untuk kelas eksperimen 35,29 dan 34,86 untuk kelas kontrol.

Nilai rata-rata kedua kelas tersebut di uji kemampuan awal dengan uji $t$ dua pihak yang ditunjukkan pada Tabel 4 merupakan ringkasan perhitungan uji kemampuan awal siswa, bahwa $t_{\text {hitung }}<t_{\text {tabel }}$. Hal ini menunjukkan kemampuan awal dari siswa sebelum diberikan perlakuan tiap-tiap kelas adalah sama.

Hasil penilaian postes yang diperoleh berdasarkan Gambar 3. menunjukkan nilai tertinggi untuk kelas eksperimen 70,00 dan 35,00 untuk nilai terendah, sedangkan untuk kelas kontrol nilai tertinggi diperoleh 65,00 dan 30,00 untuk nilai terendah. Dari hasil postes ini diperoleh nilai rata-rata untuk kelas eksperimen dan kontrol yaitu 60,43 dan 54,43. Hal ini menunjukkan ada pengaruh di setiap model yang diberikan di tiap kelas baik model PBL (kelas eksperimen) dan model konvensional (kelas kontrol).

Tabel 2. Ringkasan Hasil Uji Normalitas Kelas Eksperimen dan Kelas Kontrol

\begin{tabular}{clccc}
\hline \multirow{2}{*}{ No } & \multicolumn{1}{c}{ Data Kelas } & L hitung & $\begin{array}{c}\mathrm{L}_{\text {tabel }} \\
\alpha=0,05 \mathrm{n}=\mathrm{X}\end{array}$ & \multicolumn{1}{c}{ Kesimpulan } \\
\hline 1 & Pretes Eksperimen & 0,1406 & & Berdistribusi Normal \\
2 & Postes Eksperimen & 0,0876 & 0,1497 & Berdistribusi Normal \\
3 & Pretes Kontrol & 0,1246 & & Berdistribusi Normal \\
4 & Postes Kontrol & 0,1192 & & Berdistribusi Normal \\
\hline
\end{tabular}

Tabel 3. Ringkasan Hasil Uji Homogenitas Kedua Kelas

\begin{tabular}{|c|c|c|c|c|c|}
\hline No & Data Kelas & Varians & $F_{\text {hitung }}$ & $\mathrm{F}_{\text {tabel }}$ & Kesimpulan \\
\hline 1 & Pretes eksperimen & 110,210 & \multirow{2}{*}{1,006} & \multirow{2}{*}{1,76} & \multirow{2}{*}{ Homogen } \\
\hline 2 & Pretes kontrol & 109,539 & & & \\
\hline 3 & Postes eksperimen & 121,134 & \multirow{2}{*}{1,174} & \multirow{2}{*}{1,76} & \multirow{2}{*}{ Homogen } \\
\hline 4 & Postes kontrol & 142,311 & & & \\
\hline
\end{tabular}

Tabel 4. Ringkasan Perhitungan Uji Kemampuan Awal/ Pretes Siswa

\begin{tabular}{clcccc}
\hline No & \multicolumn{1}{c}{ Data Kelas } & Nilai Rata-Rata & $\mathrm{t}_{\text {hitung }}$ & $\mathrm{t}_{\text {tabel }}$ & Kesimpulan \\
\hline 1 & Eksperimen & 35,29 & \multirow{2}{*}{0,178} & \multirow{2}{*}{1,99} & \multirow{2}{*}{ Kemampuan Awal Sama } \\
2 & Kontrol & 34,86 & & & \\
\hline
\end{tabular}

Tabel 5. Ringkasan Perhitungan Uji Postes Siswa

\begin{tabular}{clcccc}
\hline No & Data Kelas & Nilai Rata-Rata & $\mathrm{t}_{\text {hitung }}$ & $\mathrm{t}_{\text {tabel }}$ & Kesimpulan \\
\hline 1 & Eksperimen & 60,43 & \multirow{2}{*}{22,7} & \multirow{2}{*}{1,99} & $\begin{array}{c}\text { Ada Perbedaan Hasil } \\
\text { Belajar Siswa }\end{array}$ \\
\hline
\end{tabular}




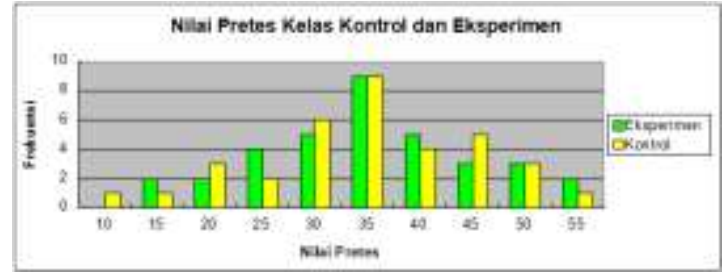

Gambar 2. Diagram Batang Nilai Pretes Kelas Eksperimen dan Kontrol

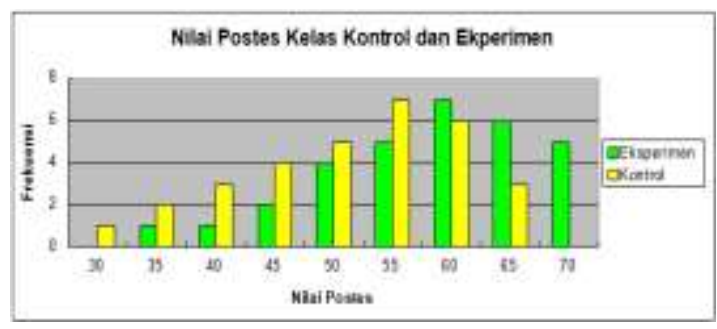

Gambar 3. Diagram Batang Nilai Postes

Kelas Eksperimen dan Kontrol

Dari kedua nilai rata-rata tersebut dilakukan pengujian kemampuan postes dengan uji t dua pihak yang ditunjukkan pada Tabel 5. bahwa $t_{\text {hitung }}>t_{\text {tabel }}$.

Hasil pengujian kemampuan postes tersebut menunjukkan bahwa ada perbedaan akibat pengaruh PBL terhadap hasil belajar fisika pada materi Listrik Dinamis bila dibandingkan menggunakan model pembelajaran konvensional.

Besarnya peningkatan hasil belajar siswa pada kelas eksperimen dikarenakan pada saat proses belajar mengajar dengan menggunakan model pemebelajaran berbasis masalah menuntut siswa untuk bekerja sama dalam memecahkan masalah yang berkaitan dengan kehidupan sehari-hari, sehingga siswa dapat memahami pelajaran yang sedang dipelajari.

Hasil ini sesuai dengan yang di teliti oleh Hayati (2011), bahwa hasil belajar siswa di kelas yang diberikan PBL menunjukkan 35 siswa tuntas secara individu dan secara kelas tuntas (87,5\%). Sibarani (2011) juga memperoleh hasil bahwa ada pengaruh antara kemampuan berpikir kritis siswa dengan menggunakan PBL dengan menggunakan model konvensional dapat dilihat dari hasil postesnya 66,74 untuk PBL dan 46,74 untuk model konvensional.

\subsection{Hasil Observasi Aktivitas Siswa}

Tabel 6. Hasil Observasi Aktivitas Siswa

\begin{tabular}{clcc}
\hline No & Pertemuan & Kelas & $\begin{array}{c}\text { Jumlah Skor } \\
\text { Rata-Rata }\end{array}$ \\
\hline 1 & Pertama & Eksperimen & 10,88 \\
2 & Kedua & & 12,80 \\
3 & Pertama & Kontrol & 7,82 \\
4 & Kedua & & 8,97 \\
\hline
\end{tabular}

Selain penilaian pengetahuan (kognitif), penilaian aktivitas siswa (psikomotor) juga dinilai, nilai aktivitas siswa juga diamati selama proses belajar dan mengajar berlangsung oleh seorang pengamat (Bapak Efriandi Purba) yang telah dilengkapi lembar observasi.

Berdasarkan Tabel 6 hasil observasi aktivitas siswa, pertemuan pertama untuk kelas eksperimen skor rata-rata 10,88. Skor ini merupakan kategori baik. Pada pertemuan kedua diperoleh skor rata-rata 12,8 dengan kategori baik, sedangkan skor rata-rata pertemuan pertama untuk kelas kontrol 7,82 dengan kategori cukup dan skor rata-rata pertemuan kedua 8,97 dengan kategori cukup. Perbandingan kedu hasil tersebut dapat disimpulkan bahwa model PBL dapat meningkatkan aktivitas siswa lebih besar jka dibandingkan dengan model konvensional. Hasil ini sesuai dengan yang dilakukan oleh Setiawan (2008), dan Tika (2008) menghasilkan bahwa model PBL meningkatkan aktivitas dan kemampuan berpikir kritis terhadap permasalahan yang disampaikan dalam pembelajaran baik fisika maupun biologi.

\section{KESIMPULAN}

Berdasarkan hasil analisis dan uji statistik serta pembahasan maka disimpulkan sebagai berikut:

1. Aktivitas siswa selama mengikuti pembelajaran dengan menggunakan model PBL diperoleh skor rata-rata 11,8 merupakan kategori baik, dan lebih aktif jika dibandingkan dengan aktivitas siswa menggunakan model pembelajaran konvensional dengan skor rata-rata 8,4 merupakan kategori cukup.

2. Terdapat perbedaan hasil belajar siswa yang lebih baik dengan nilai postest 60,43 menggunakan model PBL dibandingkan dengan nilai postest 54,43 menggunakan 
model pembelajaran konvensional pada materi listrik dinamis di kelas IX SMP.

\section{DAFTAR PUSTAKA}

Akinoglu, O dan Ruhan, O. T. 2007. The Effects of Problem Based Active Learning in Science Education on Students' Academic Achievement, Attitude and Concept Learning. Eurasia Journal of Mathematics, Science \& Technology Education. 3(1): 71-81.

Arends, R. I. 2004. Learning to teach, Edisi Ketujuh. Yogyakarta: Pustaka Pelajar.

Arikunto, S. 2002. Prosedur penelitian suatu pendekatan praktek. Jakarta: Rineka Cipta.

Setiawan, I. G. A. N. 2008. Penerapan Pengajaran Kontekstual Berbasis Masalah Untuk Mengingkatkan Hasil Belajar Biologi Siswa Kelas $\mathrm{X}_{2}$ SMA Laboratorium Singaraja. Jurnal Penelitian dan Pengembangan Pendidikan. 2(1): 42-59.

Hayati, A. 2011. Pengaruh Penerapan Model Pembelajaran Berdasarkan Masalah dan Model Pembelajaran Konvensional Pada Hasil Belajar Siswa Materi Pokok Cahaya Kelas VIII SMP Swasta Budi Mulia Medan T.P 2010/2011. Skripsi. Medan. FMIPA Universitas Negeri Medan.

Tika, I. K. 2008. Penerapan Problem Based Learning Berorientasi Penilaian Kinerja Dalam Pembelajaran Fisika Untuk Meningkatkan Kompetensi Kerja Ilmiah Siswa. Jurnal Pendidikan dan Pengajaran UNDIKSHA. (3): 684-700.

Rika, N. 2009. Perbedaam Hasil Belajar Siswa Yang Menggunakan Model Pembelajaran Berdasarkan Masalah Dengan Model Pembelajaran Konvensional Pada MAteri Pokok Usaha dan Energi di Kelas VIII SMP Swasta Rakyat Pancur Batu T.P 2009/2010. Skripsi. Medan. FMIPA Universitas Negeri Medan.

Sibarani, J. L. 2011. Pengaruh Model pembelajaran berbasis masalah Terhadap Kemampuan Berpikir Kritis Siswa Pada Materi Usaha dan Energi Kelas X SMA N 1 Doloksanggul T.P 2011/2012. Skripsi. Medan. FMIPA Universitas Negeri Medan.
Sudjana. 2002. Metoda Statistika. Bandung: PT.Tarsito Bandung. 